\title{
PHALARIS AND TALL FESCUE SEED PRODUCTION: VOLUNTEER CONTROL AND HERBICIDE TOLERANCE
}

\author{
K. REDDY, M.P. ROLSTON and W.J. ARCHIE
}

AgResearch, P.O. Box 60, Lincoln

\begin{abstract}
Experiments in grass seed crops investigated the control of volunteers in phalaris (Phalaris aquatica) and tolerance of phalaris seed crops to four herbicides and tall fescue (Festuca arundiacea) to eight herbicides. Atrazine at $2040 \mathrm{~g} / \mathrm{ha}$ gave $94 \%$ control of volunteer phalaris and both atrazine at $2040 \mathrm{~g} / \mathrm{ha}$ and ethofumesate at $2000 \mathrm{~g} / \mathrm{ha}$ showed good tolerance with phalaris seed yields of 760 and $750 \mathrm{~kg} / \mathrm{ha}$ compared to untreated control which had a seed yield of $620 \mathrm{~kg} / \mathrm{ha}$. Tall fescue seed yields showed good tolerance to terbuthylazine at $750 \mathrm{~g} / \mathrm{ha}$, prodiamine at $65 \mathrm{~g} / \mathrm{ha}$, chlorpropham at $1200 \mathrm{~g} / \mathrm{ha}$, diuron at $1800 \mathrm{~g} / \mathrm{ha}$ and oxyflurofen at $288 \mathrm{~g} / \mathrm{ha}$ with seed yields of $2580-2730 \mathrm{~kg} / \mathrm{ha}$ compared to untreated of $2200 \mathrm{~kg} / \mathrm{ha}$. In the second year, burn treatments with metolachlor at $1920 \mathrm{~g} / \mathrm{ha}$ gave $88 \%$ volunteer control with a seed yield of $1380 \mathrm{~kg} / \mathrm{ha}$ compared with untreated control of $1090 \mathrm{~kg} / \mathrm{ha}$.
\end{abstract}

Keywords: Festuca arundiaceae, herbicide, Phalaris aquatica, seed, tall fescue, volunteer control.

\section{INTRODUCTION}

Phalaris (Phalaris aquatica) and tall fescue (Festuca arundiacea) are now important forage species in New Zealand agriculture because of their ability to grow well and survive in drought prone areas. Tall fescue is also an important turf grass with seed exports to the USA markets.

Phalaris and tall fescue seed crops can be harvested for six consecutive seasons under the New Zealand seed certification scheme. Volunteer crop seedlings are generally the most common weed occurring in high densities in established phalaris paddocks grown for seed because of the ease with which seedheads shatter at harvest (Reddy et al. 1993). Volunteer seedlings increase competition, reduce seed yields and contribute to genetic drift in the crop as they are a lower generation than the parent crop. In New Zealand many tall fescue and phalaris seed growers use atrazine to remove annual grasses, volunteer and broadleaf weed seedlings (Rolston and Archie 1990). Seed growers are concerned at the potential for herbicide residues from atrazine to affect subsequent crops, while in some areas of Canterbury, there are increasing concerns about triazine residues in soil and groundwater. In Oregon oxyflurofen and pendimethalin have been shown to be effective alternatives to atrazine for use in tall fescue seed crops (Mueller-Warrant et al. 1995).

This paper reports on crop tolerance trials to determine a range of herbicides suitable for use in established phalaris and tall fescue seed crops for the control of volunteer seedlings in order to identify alternative herbicides to atrazine.

\section{MATERIALS AND METHODS}

In all trials herbicides were applied from a compressed gas backpack sprayer with a $2.0 \mathrm{~m}$ wide boom with 4 nozzles, applying the treatments at 250 litre/ha and $200 \mathrm{kPa}$. Seedling control and crop damage were visually assessed. Dry matter and tiller densities were assessed from $0.25 \mathrm{~m}^{2}$ quadrats, and seed yield components were based on 20 seed heads per plot. Crops were harvested by cutting $1.0 \mathrm{~m}^{2}$ quadrats from each plot which were air-dried in hessian bags before being threshed, cleaned in a screen-air separator and weighed to give seed yield. Data analysis was undertaken with Genstat. 
Trial 1. Phalaris volunteer control and herbicide tolerance

The trial was sown in autumn 1994 with phalaris (Phalaris aquatica) cv. Grasslands Maru on Wakanui silt loam on a seed grower's farm at Lowcliff, Ashburton. The trial was conducted in 1995 on a second year crop. The residues from the first crop harvest were burnt in autumn before the application of herbicides.

Four herbicides were applied on 8 May 1995 using a factorial randomised complete block design with four replications and a plot size of $8 \mathrm{~m} \times 5 \mathrm{~m}$. The herbicide treatments and application rates used were; atrazine (Gesaprim 500) at $2000 \mathrm{~g} / \mathrm{ha}$; ethofumesate (Nortron) at $2000 \mathrm{~g} / \mathrm{ha}$; simazine (Gesatop 500) at $1800 \mathrm{~g} / \mathrm{ha}$ and TCA $+2,2$-DPA (Teedal) at $4410+770 \mathrm{~g} / \mathrm{ha}$. The crop was evaluated on 4 October and 20 December, and harvested for seed yield on 24 January 1996.

Trial 2. Tall fescue herbicide tolerance

The second and third trials were sown in 1995 with an amenity tall fescue (Festuca arundinacea) cv. SF19 on a seed grower's farm at Geraldine. Trial 2 was conducted in 1996/97 season on a second year crop. After the harvest of the first crop, the straw residues were bailed in summer. Eight herbicides were applied on 21 February 1996 in a factorial randomised complete block design with four replications and a plot size of $20 \mathrm{~m}^{2}$. The herbicide treatments and application rates used were; atrazine at $510 \mathrm{~g} / \mathrm{ha}$, terbuthylazine (Gardoprim) at $750 \mathrm{~g} / \mathrm{ha}$, prodiamine (Barricade) at $65 \mathrm{~g} / \mathrm{ha}$, chlorpropham (Chloro-IPC at $1200 \mathrm{~g} / \mathrm{ha}$, diuron (Karmex) at $1800 \mathrm{~g} / \mathrm{ha}$, metolachor (Dual) at $1920 \mathrm{~g} /$ ha, pendimethalin (Stomp) at $2600 \mathrm{~g} / \mathrm{ha}$ and oxyflurofen (Goal XL) at $288 \mathrm{~g} / \mathrm{ha}$.

\section{Trial 3. Tall fescue volunteer control and herbicide tolerance}

The third trial was conducted in 1997/98 season on a third year crop in the same paddock as that of trial 2, after seed harvest straw residues were either bailed or burnt in summer. The three most promising herbicides were applied in February 1997, using a split plot design with main plots being either straw residue baled or burnt treatments. The herbicide treatments and application rates used were; terbuthylazine at $1000 \mathrm{~g} / \mathrm{ha}$, chlorpropham at $1200 \mathrm{~g} / \mathrm{ha}$, simazine at $1020 \mathrm{~g} / \mathrm{ha}$ and metolachlor at $1920 \mathrm{~g} / \mathrm{ha}$.

\section{Phalaris}

\section{RESULTS AND DISCUSSION}

Before treatment application, the average volunteer density was 1730 seedling/ $\mathrm{m}^{2}$. All herbicide treatments gave good to excellent control of volunteer phalaris seedlings with atrazine proving most effective, followed by TCA + 2,2-DPA (Table 1). However the TCA + 2,2-DPA treatment resulted in significant crop damage resulting in significantly lower dry matter and crop tiller densities in October (Table 1). Before application of treatments, the crop averaged 1570 plants $/ \mathrm{m}^{2}$. The crop had recovered from these effects by the December samplings (Table 1).

TABLE 1: Percentage volunteer seedling control, crop damage, dry matter and tiller population in phalaris treated with herbicides.

\begin{tabular}{lccccccc}
\hline Treatment & $\begin{array}{c}\text { Rate } \\
(\mathrm{g} \text { ai } / \mathrm{ha})\end{array}$ & $\begin{array}{c}\text { Seedling } \\
\text { control } \\
(\%)\end{array}$ & $\begin{array}{c}\text { Crop } \\
\text { damage } \\
(\%)\end{array}$ & $\begin{array}{c}\text { Dry } \\
\text { matter } \\
(\mathrm{kg} / \mathrm{ha})^{1}\end{array}$ & $\begin{array}{c}\text { Tillers } \\
\left(\mathrm{No} / \mathrm{m}^{2}\right)^{1}\end{array}$ & $\begin{array}{c}\text { Dry } \\
\text { matter } \\
(\mathrm{kg} / \mathrm{ha})^{2}\end{array}$ & $\begin{array}{c}\text { Tillers } \\
\left(\mathrm{No} / \mathrm{m}^{2}\right)^{2}\end{array}$ \\
\hline Control & 0 & 0 & 0 & 1890 & 4720 & 12940 & 1400 \\
Atrazine & 2000 & 94 & 8 & 1390 & 2910 & 15150 & 1480 \\
Ethofumesate & 2000 & 44 & 0 & 1410 & 3920 & 13310 & 1530 \\
Simazine & 1275 & 67 & 3 & 1400 & 3130 & 13890 & 1870 \\
TCA + & $4410+770$ & 85 & 65 & 538 & 1030 & 13660 & 1570 \\
2,2-DPA & & & & & & & \\
LSD $(<0.05)$ & & 9 & 1.4 & 134 & 141 & 1219 & 187 \\
\hline
\end{tabular}

${ }^{1}$ Sampled on 4 October

${ }^{2}$ Sampled on 20 December 
Atrazine, ethofumesate and simazine treated plots had $18 \%, 15 \%$ and $14 \%$ more seedheads than the untreated control, respectively, whereas TCA + 2,2-DPA had 4\% less seedheads than the control plots (Table 2) largely due to the significant crop injury in October (Table 1). However, even with the high initial level of crop damage from TCA +2, 2 DPA, there was no final reduction in seed yield. Seed yields of atrazine and ethofumesate were also 21 and $22 \%$ higher than the untreated control, representing an increase of between 135 and $143 \mathrm{~kg} / \mathrm{ha}$. Florets per panicle and side branches per panicle were not affected by the treatments (Table 2).

TABLE 2: Seed yield and seed head components of phalaris treated with different herbicides.

\begin{tabular}{lccccc}
\hline Treatment & $\begin{array}{c}\text { Rate } \\
(\mathrm{g} / \mathrm{ha})\end{array}$ & $\begin{array}{c}\text { Seedheads } \\
\left(/ \mathrm{m}^{2}\right)\end{array}$ & $\begin{array}{c}\text { Florets } \\
(/ \text { panicle })\end{array}$ & $\begin{array}{c}\text { Side branches } \\
(/ \text { panicle })\end{array}$ & $\begin{array}{c}\text { Seed yield } \\
(\mathrm{kg} / \mathrm{ha})\end{array}$ \\
\hline Control & & 794 & 557 & 15.6 & 618 \\
Atrazine & 2000 & 938 & 524 & 18.0 & 761 \\
Ethofumesate & 2000 & 914 & 556 & 18.2 & 753 \\
Simazine & 1275 & 892 & 534 & 19.1 & 611 \\
TCA + & $4410+770$ & 761 & 508 & 16.7 & 687 \\
2,2-DPA & & & & & \\
LSD $(<0.05)$ & & 95 & 78 & 3.7 & 84 \\
\hline
\end{tabular}

\section{Tall fescue}

In tall fescue, control of volunteer tall fescue seedlings and consequent removal of competition resulted in significant yield responses. The mean seed yield of the untreated control was $2200 \mathrm{~kg} / \mathrm{ha}$. Five herbicides resulted in significantly higher seed yields (average $2660 \mathrm{~kg} / \mathrm{ha}$ ) than either the untreated control or atrazine (Table 3). Tall fescue had good tolerance to prodiamine, chlorpropham, diuron, terbuthylazine and oxyflurofen. These results show that atrazine could be replaced with other herbicides to achieve the same or even better results.

TABLE 3: Seed yield of second year tall fescue treated with different herbicides.

\begin{tabular}{lcc}
\hline Herbicide & Rate $(\mathrm{g}$ ai/ha $)$ & Seed yield $(\mathrm{kg} / \mathrm{ha})$ \\
\hline Untreated control & 0 & 2200 \\
Atrazine & 510 & 2150 \\
Prodiamine & 650 & 2710 \\
Chlorpropham & 1200 & 2700 \\
Diuron & 1800 & 2580 \\
Metolachor & 1920 & 2410 \\
Terbuthylazine & 750 & 2730 \\
Oxyflurofen & 288 & 2580 \\
Pendimethalin & 2600 & 2360 \\
& & 350
\end{tabular}

In the third year tall fescue seed crop, volunteer control tended to be higher in baled plots, while seed yields from burnt plots tended to be higher. This suggests that carbon from the burning may have partially inactivated the herbicides (Rolston et al. 1979) (Table 4). Seed yields were lower than the previous year because of drought conditions. 
TABLE 4: Tall fescue volunteer seedling control and seed yields (kg/ha) where straw was burnt or baled after harvest, and before herbicide application.

\begin{tabular}{|c|c|c|c|c|c|}
\hline \multirow[t]{2}{*}{ Treatments } & \multirow[t]{2}{*}{ Rate } & \multicolumn{2}{|c|}{ Volunteer Control (\%) } & \multicolumn{2}{|c|}{ Seed Yield } \\
\hline & & Burnt & Baled & Burnt & Baled \\
\hline untreated control & 0 & 21 & 0 & 1090 & 920 \\
\hline $\begin{array}{l}\text { Chlorpropham }+ \\
\text { simazine }\end{array}$ & $1200+1020$ & 69 & 86 & 1160 & 1040 \\
\hline Metolachor & 1920 & 88 & 88 & 1380 & 990 \\
\hline Terbuthylazine & 1000 & 50 & 78 & 1120 & 1090 \\
\hline $\operatorname{LSD}(<0.05)$ & & \multicolumn{2}{|c|}{23} & \multicolumn{2}{|c|}{172} \\
\hline
\end{tabular}

\section{CONCLUSION}

In multi-year harvest seed crops of established phalaris and tall fescue, volunteer crop seedlings establishing from seed lost during harvest was reduced by $70-90 \%$ with herbicides with little crop damage. The herbicides evaluated all showed reasonable to good control of volunteers, thus reducing the potential for genetic drift during the different generations grown during multiplication of a cultivar. In phalaris, the best herbicide treatment (increased seed yield and volunteer control) was atrazine followed by ethofumesate. In tall fescue, chlorpropham, metolachlor, terbuthylazine, diuron and prodiamine all showed promise with reasonable volunteer control, although seed yields were often similar to the untreated control. The herbicide treatments often (but not always) enhanced seed yield, and this increase was generally associated with more seed heads and/or a reduction in seedling volunteers. The trials demonstrated that several herbicides can be used as alternatives to atrazine, especially in tall fescue. Alternative non-triazine herbicides would include chlorpropham, diuron, metolachlor and oxyflurofen. However all the non-triazine alternatives are more expensive than atrazine, but could be used where atrazine residues are of concern.

\section{ACKNOWLEDGEMENTS}

The authors wish to thank Keith Widdup for his editorial comments, John Morrow (Ashburton) and Roger Slater (Timaru) for making the trial site available.

\section{REFERENCES}

Mueller-Warrant, G.W., Young, W.C. and Mellbye, M.E., 1995. Residue removal method and herbicides for tall fescue seed production: I. Weed control.Agronomy J. 87:551-558.

Reddy, K., Scott, W. R. and Lucas, R.J., 1993. Influence of harvest date on the yield and quality of seed of phalaris. Proc. XV11 Intern. Grassland Congress: 16851686.

Rolston, M.P. and Archie, W.J., 1990. Herbicide tolerance of established tall fescue and phalaris seed crops. Proc. 43 ${ }^{\text {rd }}$ N.Z. Weed and Pest Control Conf.: 134-137.

Rolston, M.P., Lee, W.O. and Appleby, A.P., 1979. Volunteer legume control in legume seed crops with carbon bands and herbicides. J. Agronomy 71: 665-670. 